\title{
Diversity of Arbuscular Mycorrhizal Fungi in Agroforestry, Conventional Plantations and Native Forests in Roraima State, Northern Brazil
}

\author{
Tharles Mesquita Araújo ${ }^{1}$, Krisle da Silva ${ }^{2}$, Gilmara Maria Duarte Pereira ${ }^{3}$, Alexandre Curcino ${ }^{1}$, \\ Sidney Luiz Stürmer ${ }^{4} \&$ Plinio Henrique Oliveira Gomide ${ }^{1}$ \\ ${ }^{1}$ State University of Roraima, Boa Vista, RR, Brazil \\ ${ }^{2}$ Embrapa Florestas, Colombo, PR. Brazil \\ ${ }^{3}$ Federal University of Roraima, Boa Vista, RR, Brazil \\ ${ }^{4}$ Universidade Regional de Blumenau, Blumenau, SC, Brazil \\ Correspondence: Tharles Mesquita Araújo, State University of Roraima, Rua Sete de Setembro, 231-Canarinho, \\ 69306-530, Boa Vista, RR, Brazil. E-mail: mesquita.rr@hotmail.com
}

Received: April 9, $2019 \quad$ Accepted: June 9, $2019 \quad$ Online Published: August 31, 2019

doi:10.5539/jas.v11n14p282 URL: https://doi.org/10.5539/jas.v11n14p282

\begin{abstract}
Arbuscular mycorrhizal fungi (AMF) are important components of the soil microbiota in terrestrial ecosystems, under the influence of various factors such as soil use and management, and can be adapted to a structure and diversity of fungal communities. The aim of this survey was to evaluate the influence of different systems of land use and management on AMF diversity in the Roraima State, Brazil. We collected soil samples in agroforestry, conventional soybean planting, conventional corn and native forest. After 150 days of incubation in a greenhouse, we extracted the spores in order to evaluate AMF, volume and to determine taxonomic identification. We found 16 species of AMF and the genus Acaulospora was the most frequent, followed by Glomus. Soil under agroforestry system had the highest species richness and the native forest, the lowest. On the other hand, soybean and corn areas presented greater density values than agroforestry system and native forest. In the agroforestry system, SOM attributes, $\mathrm{Al}^{3+}$ and $\mathrm{H}+\mathrm{Al}$ had influence in $\mathrm{AMF}$ species richness. Thus, agroforestry constitute sustainable alternative influencing AMF communities in these ecosystems.
\end{abstract}

Keywords: sustainability, management systems, microbiological, Amazon

\section{Introduction}

The term "soil quality" includes different functions: ecosystem management, water maintenance and air quality to promote life and health of animals and plants. The soil quality can be improved with the incorporation of vegetal cover (for example to provide natural leaf-fall), because it assures an incorporation of nutrients into the soil, so aiding the maintenance of soil productivity. The ability of the soil to fulfill these functions is evaluated through the measurement of physical, chemical and biological properties, known as "soil quality indicators" (Shukla \& Ebinger, 2006).

Intensification of anthropic activities can decrease key biological processes, promoting physical degradation of the soil, with impacts on populations of organisms that potentiate soil aggregation, compaction and stability. Such actions may then interfere with plant nutrition and growth (Trindade, Grazziotti \& Tótola, 2000).

In the Amazon, most of the soil is firm, highly acidic and strongly deficient in nutrient, which may interfere in both growth and development of non-native plants, limiting the nature and extent of regional agriculture (Oliveira et al., 1999). Costa et al. (1999), studying the AMF communities under different land use and management systems in the state of Rondônia, northern Brazil, detected that mean AMF spore density in soils under the original forest cover (184 spores/100 g soil) was modified according to subsequent land use form. Spore numbers were reduced in soil on land where the forest had been cleared (118 spores/100 $\mathrm{g}$ of soil), while areas that were cleared then planted with legumes had a spore (179 spores/100 $\mathrm{g}$ of soil) similar to the one of the original forest. 
In order to understand the functioning and diversity of AMFs under different systems of land use and management in the Roraima state, northern Brazil, the aim of this survey was to investigate the specific composition of AMF communities and the relationship between diversity of these organisms and chemical characteristics of soils. We investigated four different systems of land use: native forest, agroforestry system, conventional corn and soybean planting.

\section{Methods}

\subsection{Sampling}

We collected soil samples in two areas of the Brazilian Agricultural Research Institute (EMBRAPA-Roraima). The first area, Confiança Experimental Field $\left(02^{\circ} 15^{\prime} 00^{\prime \prime} \mathrm{N}\right.$ and $\left.60^{\circ} 39^{\prime} 54^{\prime \prime} \mathrm{W}\right)$, located in the municipality of Cantá, is characterized by forest vegetation and an Ami (Koppen) climate, with rainy season from May to July and rainfall between 1,795 and $2.285 \mathrm{~mm}$ per year (Mourão et al., 2003). The soil is classified as dystrophic Yellow Argisol, containing clay of low activity and textural B horizon (Solos, 1999). In this area, soil samples were collected in an Agroforestry System (AFS) at the age of 18 and composed of the following plant species: gliricidia (Gliricidia sepium), Brazil nut (Bertholetia excelsa), cupuaçu (Theobroma grandiflorum), abiu (Micropholis venulosa), cupiúba (Goupia glabra), coffee (Coffea canefora), rain tree (Samanea saman), peach palm (Bactris gasipaes) and andiroba (Carapa guianensis).

The second area, the Serra da Prata Experimental Field $\left(02^{\circ} 23^{\prime} 25.3^{\prime \prime} \mathrm{N}\right.$; $\left.060^{\circ} 58^{\prime} 59.8^{\prime \prime} \mathrm{W}\right)$ is located in the municipality of Mucajaí and has a climate of type Am, with a rainy season between April and August and dry season from September to March, with a soil classified as Yellow Latosol. Total annual rainfall varies from 1510 to $2145 \mathrm{~mm}$ per year, with an annual average of $1844 \mathrm{~mm}$ (Mourão et al., 2003).

In both areas, soil samples were collected in native forest and conventional corn and soybean plantations. The latter two areas $(10 \mathrm{~m} \times 10 \mathrm{~m}$ plots $)$ underwent two types of fertilization and a general correction of the soil, involving (for both plantations) $1500 \mathrm{~kg}$ of dolomitic limestone, $100 \mathrm{~kg}$ of potassium chloride, $500 \mathrm{~kg}$ of triple superphosphate, $50 \mathrm{~kg}$ of FTE/BR12 (micronutrients); Soil/corn planting fertilization: $100 \mathrm{~kg}$ of potassium chloride, $500 \mathrm{~kg}$ of triple superphosphate, $50 \mathrm{~kg}$ FTE, with $200 \mathrm{~kg}$ of urea (corn only). Cover fertilization was 100 $\mathrm{kg}$ of potassium chloride (corn/soybean) and $300 \mathrm{~kg}$ of urea (corn)/hectare.

Sampling protocol followed Nicolodi et al. (2002), four composite soil samples of approximately $1 \mathrm{~kg}$ were taken from the AFS and, conventional soybean and corn areas, in the latter two, samples were perpendicular to the planting line.

The samples were conditioned in sterile plastic bags, homogenized and stored in a refrigerator $\left(4^{\circ} \mathrm{C}\right)$ until further processing. One part of the collected soil was destined for chemical analysis, the other for the extraction of spores.

\subsection{Chemical Analysis}

Macronutrient analyses were performed at the EMBRAPA/RR Soil Analysis Laboratory, using Embrapa (2009) methodology. The $\mathrm{pH}$ analyzes were done in water, potential acidity and exchangeable by titration, and the exchangeable acidity was extracted with $1 \mathrm{M}$ potassium chloride solution. Calcium and magnesium were determined by flame atomic absorpion spectroscopy. For determination of the potential acidity, it was extracted with $0.1 \mathrm{M}$ calcium chloride solution. For the determinations of $\mathrm{P}$ and $\mathrm{K}$, a Melich 1 extractor was used, and phosphorus was analyzed by colorimetric reaction with ammonium molybdate and potassium by flame photometry (Vitoria, 1969).

\subsection{Establishment of Trap Cultures}

Trap cultures were established by mixing $50 \mathrm{~g}$ of native soil from each sample and homogenizing this with medium sand autoclaved three times at $121^{\circ} \mathrm{C}$ for 1 hour.

The host was Congo grass (Urochloa ruziziensis = Brachiaria ruziziensis) $(15 \mathrm{~g}$ of seed per pot, $2 \mathrm{~cm}$ of depth), with pots being kept in a greenhouse for 150 days and irrigated periodically. If they showed any symptoms of deficiency, $20 \mathrm{~mL}$ of nutrient solution (Hoogland \& Arnon, 1950) were added (once a month) in order to meet the nutritional needs of the plants. Pot positions on the workbench were changed frequently and, to stimulate plant root production, pruning of the aerial part was carried out, when it was well developed. Trapping cultures were then disassembled (aerial part was removed and the rest of the material stored in plastic bags and kept at $4{ }^{\circ} \mathrm{C}$ ), and FMA spores later extracted from the soil.

Spore extraction was carried out by wet sieving decantation (Gerdemann \& Nicolson. 1963) from $1000 \mathrm{~g}$ of soil TFSA. An aliquot of $1 \mathrm{~mL}$ of water/spore suspension was transferred to fluted plates for determination of the number of spores per $\mathrm{mL}$. The suspension was examined on the plate using a Nikon SMZ-U stereomicroscope for 
counting, selection and characterization of the spores, which were grouped into morphotypes according to morphology (color, size, shape). Spores were mounted on permanent slides with pure polyvinyl lactoglycerol (PVLG) and PVLG with Melzer's reagent $(1: 1 \mathrm{v} / \mathrm{v})$.

Slides were kept for 5 days at room temperature and 2-3 days at $60^{\circ} \mathrm{C}$ in a greenhouse. Taxonomic identification followed the descriptions of the reference cultures stored in the International Culture Collection of Arbuscular and Vesicular-Arbuscular Mycorrhizal Fungi-INVAM (http://invam.caf.wvu.edu). Interpretation of the taxonomic characteristics was made via optical microscope observations with light-field illumination and objective of immersion.

\subsection{Analysis of AMF Communities}

AMF communities were analyzed both quantitatively and qualitatively. The presence of spores of a particular species in each sample was used to calculate the frequency of occurrence (FO) of that species, using the equation: $\mathrm{Fi}=\mathrm{Ji} / \mathrm{k}$, where, $\mathrm{Fi}$ = frequency of occurrence of species $\mathrm{i} ; \mathrm{Ji}=$ number of samples in which species $\mathrm{i}$ occurred; and $\mathrm{k}=$ total number of soil samples. The total number of AMF species obtained represented the species richness in the analyzed samples.

The diversity in the different systems was analyzed with Shannon index. Canonical Analysis (CCA) was performed to state correspondence between the AMF species and the chemical attributes in the different systems of the soil use. AMF similarity among different soils use was calculated using Bray-Curtis index and Ward's method to construct the similarity dendogram. We performed the statistical analyses with software R Core Team (2018).

\section{Results and Discussion}

In the chemical characterization of the different land use and management systems, the higher $\mathrm{pH}$ values in soil under soybean and corn when compared to the AFS area can be explained by the chemical correction of the soil that preceded the planting of these crops (Table 1)

Table 1. Soil chemical attributes in areas of native forest, agroforestry system (AFS), conventional soybean and corn planting in the state of Roraima. Northern Brazil.

\begin{tabular}{lllllllll}
\hline Trataments & $\mathbf{p H}$ & $\mathbf{C a}^{2+}$ & $\mathbf{M g}^{\mathbf{2 +}}$ & $\mathbf{K}^{+}$ & $\mathbf{A l}^{3+}$ & $\mathbf{H}+\mathbf{A l}$ & $\mathbf{P}$ & $\mathbf{M O S}$ \\
\hline & $\mathrm{H}_{2} \mathrm{O}$ & $-----------------\mathrm{cmol}_{\mathrm{c}} \mathrm{dm}^{-3}$ & ----------------- & $\mathrm{mg} \mathrm{dm}^{-3}$ & $\mathrm{~g} \mathrm{~kg}^{-1}$ \\
Native Forest & $5.70 \mathrm{a}$ & $2.71 \mathrm{a}$ & $1.04 \mathrm{a}$ & $0.07 \mathrm{~b}$ & $0.03 \mathrm{~b}$ & $3.24 \mathrm{~b}$ & $2.75 \mathrm{c}$ & $29.4 \mathrm{a}$ \\
$\mathrm{SAF}$ & $4.60 \mathrm{c}$ & $0.41 \mathrm{c}$ & $0.15 \mathrm{~b}$ & $0.08 \mathrm{~b}$ & $0.70 \mathrm{a}$ & $7.46 \mathrm{a}$ & $5.29 \mathrm{bc}$ & $25.4 \mathrm{a}$ \\
Soey & $5.27 \mathrm{~b}$ & $1.34 \mathrm{~b}$ & $0.24 \mathrm{~b}$ & $0.17 \mathrm{a}$ & $0.08 \mathrm{~b}$ & $3.07 \mathrm{~b}$ & $38.11 \mathrm{a}$ & $17.5 \mathrm{~b}$ \\
Corn & $5.32 \mathrm{~b}$ & $1.49 \mathrm{~b}$ & $0.25 \mathrm{~b}$ & $0.05 \mathrm{~b}$ & $0.05 \mathrm{~b}$ & $2.93 \mathrm{~b}$ & $25.72 \mathrm{ab}$ & $16.9 \mathrm{~b}$
\end{tabular}

Note. Means followed by the same letters in the column do not differ from each other by the Tukey test at $5 \%$ of probability.

Amazonian soils, especially in the state of Roraima, are strongly weathered, so that chemical and biological agents have been acting slowly on them for thousands of years, stimulating the loss of exchangeable bases, and contributing to notably acid soils (Vendrame, 2011).

Liming favors the increase of $\mathrm{pH}$, base saturation and calcium and magnesium contents, decreasing the solubility of some ions that, in high concentration, are toxic to most cultivated plants, such as aluminum and the manganese (Bernardi et al., 2018). Thus, $\mathrm{Al}$ and $\mathrm{H}+\mathrm{Al}$ levels are commonly reduced in the cultivated areas, also due to the liming effect. The AFS area, where no soil liming occurred, had the highest concentration of exchangeable aluminum and potential acidity.

In the soil under conventional soybean and corn crops, observed soil organic matter (SOM) values indicate low levels of SOM (i.e., less than [1.5\%]: Fageria. 2004). The higher SOM levels found in native forest area and agroforestry system are probably result from the significant amount of vegetal remains in the soil and the presence of residues of root systems of the native vegetation that were not disturbed, as well as the presence of different tree species associated with agricultural species. Roraima soils have a naturally low organic matter content that is attributed to low biomass incorporation of the natural vegetation and to the high microbial activity - a result of the region's hot and humid climate (Benedetti et al., 2011). In areas with native vegetation, SOM is stable, but when submitted to agricultural use, a marked reduction in SOM content can occur (Salton et al., 2008). The lower SOM content in cultivated areas is due to soil uptake which increases the soil oxygen uptake and, consequently, 
stimulates activity of the heterotrophic microbiota that decomposes the SOM. In turn, micobiota is reduced in such soil because liming favors an increase in $\mathrm{pH}$, base saturation and calcium and magnesium contents, as well as decrease the solubility of some ions. These ions, in high concentration, are toxic to most cultivated plants, such as aluminum and manganese (Bernardi et al., 2018). Thus, it is possible to identify a reduction of $\mathrm{Al}$ and $\mathrm{H}+\mathrm{Al}$ contents in the cultivated areas, also due to the liming effect (Table 1). The AFS area, where there was no soil liming, had the highest concentration of exchangeable aluminum and potential acidity.

Levels of $\mathrm{Ca}^{2+}, \mathrm{Mg}^{2+}$ and $\mathrm{K}^{+}$showed significant differences between the studied areas (Table 1). The native forest area had the highest levels of $\mathrm{Ca}^{2+}$ and $\mathrm{Mg}^{2+}$ when compared to the other systems. However, the concentrations of $\mathrm{K}^{+}$and $\mathrm{P}$ were higher in the soya and corn areas. For SOM, native forest and AFS soils gave higher values compared to the other treatments, with $29.4 \mathrm{~g} \mathrm{~kg}^{-1}$ and $25.4 \mathrm{~g} \mathrm{~kg}^{-1}$ (AFS), $17.5 \mathrm{~g} \mathrm{~kg}^{-1}$ (soybean) and $16.9 \mathrm{~g} \mathrm{~kg}^{-1}$ (corn).

Soybean (39.5 spores per $\mathrm{mL}$ ) and corn (35.6 spores per $\mathrm{mL}$ ) presented greater density values than agroforestry system (20.1 spores per $\mathrm{mL}$ ) and native forest (18.1 spores per $\mathrm{mL}$ ) (Table 2$)$. This result can be associated to the management of both soybean and corn areas, which had their soil disturbed with plowing process, making them more stressful to the edaphic microbiota, which may have contributed to the greater sporulation.

According to Oehl et al. (2003), cultivated areas with high management intensity may favor species that have the ability to develop quick sporulation.

The low value of spores in the native forest is related to the stability of the natural ecosystems, environments with two main features: (i) presence of hosts and (ii) absence of intense variations in the soil fertility. These features ensure the survival of species of fungi with low capacity of natural sporulation or that produce spores with low resistance to adverse conditions.

In different systems of use in the Amazon, Leal et al. (2009), evaluating the occurrence and diversity of AMF, found spores density in native forest was significantly lower if compared to the other systems of soil use, which had 30 spores in $50 \mathrm{~mL}$ of soil recovered.

Carneiro et al. (2009) evaluated the physical, chemical and biological attributes of Cerrado soil under different systems of use and management. They found low sporulation in the native environment (Cerrado: 428 spores / 50 $\mathrm{mL}$ soil) when compared to planting over straw with soybean ( 941 spores / $50 \mathrm{~mL}$ soil) and corn (940 spores / 50 $\mathrm{mL}$ soil) environments, which obtained almost twice more spores. These studies corroborate with the results found in this study where the spore density found in the native forest environment was lower than the other evaluated environments. The Spore density and AMF diversity are used as indicators of interference in natural ecosystems (Siqueira et al., 1989).

Table 2. Spores density (mean \pm standard deviation) of arbuscular mycorrhizal fungi found in different soil use systems in Roraima

\begin{tabular}{ll}
\hline Treatments & spores $\mathbf{~ m L}^{-1}$ \\
\hline Native forest & $18.1 \pm 3.4 \mathrm{~b}$ \\
Agroforesty system & $20.1 \pm 5.8 \mathrm{~b}$ \\
Soy & $39.5 \pm 6.8 \mathrm{a}$ \\
Maize & $35.6 \pm 13.6 \mathrm{a}$ \\
\hline
\end{tabular}

Note. The mean spores $\mathrm{mL}^{-1}$ obtained from $100 \mathrm{~g}$ of soil. Means followed by the same letter do not differ by Tukey's test $(\mathrm{p}<0.005)$.

A total of 16 AMF species belonging to 5 families were found in the soil samples (Table 3). The most frequent species were those belonging to the genus Acaulospora, followed by the genus Glomus. Acaulospora mellea and Glomus sp 1 were species that occurred most frequently in the different studied systems. The genera Acaulospora and Glomus occurred in all areas, always at higher percentages compared to the other recorded species. The genus Ambispora was found in the conventional soybean system. The species Claroideoglomus etunicatum occurred only in the agroforestry system. Gigaspora sp., and Dentiscutata heterogama occurred in conventional corn and soybean crops, respectively. Stürmer et al. (2018) identified of 23 AMF species of soils under savanna vegetation in Roraima, through field samples and culture traps. Species included Gigaspora margarita, Dentiscutata heterogama and Glomus sp1. They also highlighted the importance of soil chemical parameters, as determinants of AMF diversity, considering they were positively correlated with higher Glomus abundance. 
Table 3. Frequency of occurrence (\%), Shannon index and species richness of arbuscular mycorrhizal fungal species in distinct land use systems in the state of Roraima

\begin{tabular}{|c|c|c|c|c|c|}
\hline Familys/Species of AMF & NF & AFS & PCS & PCM & FO (\%) \\
\hline \multicolumn{6}{|l|}{ Acaulosporaceae } \\
\hline Acaulospora sp. (sp1) & & & & 1 & 25 \\
\hline Acaulospora foveata (sp2) & & 3 & & & 25 \\
\hline Acaulospora lacunosa (sp3) & & 2 & & & 25 \\
\hline Acaulospora laevis (sp4) & & 1 & & & 25 \\
\hline Acaulospora mellea (sp5) & $3 *$ & 8 & 4 & 1 & 100 \\
\hline Acaulospora morrowiae (sp6) & & 1 & & & 25 \\
\hline Acaulospora rehmii (sp7) & & 1 & & & 25 \\
\hline Acaulospora tuberculata $(\mathrm{sp} 8)$ & & & 1 & & 25 \\
\hline \multicolumn{6}{|l|}{ Ambisporaceae } \\
\hline Ambispora leptoticha $(\mathrm{sp} 9)$ & & & 1 & & 25 \\
\hline \multicolumn{6}{|l|}{ Claroideoglomeraceae } \\
\hline Claroideoglomus etunicatum (sp10) & & 1 & & & 25 \\
\hline \multicolumn{6}{|l|}{ Glomeraceae } \\
\hline Glomus sp1 (sp11) & 14 & 9 & 9 & 7 & 100 \\
\hline Glomus sp2 (sp12) & & 2 & 1 & & 50 \\
\hline Glomus sp3 (sp13) & & & 2 & & 25 \\
\hline Glomus sp4 (sp14) & & & 1 & 1 & 50 \\
\hline \multicolumn{6}{|l|}{ Gigasporaceae } \\
\hline Gigaspora sp. (sp15) & & 1 & & & 25 \\
\hline Dentiscutata heterogama (sp16) & & & 1 & 3 & 50 \\
\hline Total Richness & 2 & 10 & 8 & 5 & \\
\hline Index of Shannon (H') & 0.47 & $1.90^{-}$ & 1.66 & 1.26 & \\
\hline
\end{tabular}

Note. NF: native forest; AFS: agroforestry system; PCS: conventional soybean planting; PCM: conventional corn planting; FO: Frequency of occurrence. H': Shannon diversity index. If two variables have different letters, they are significantly different $(*)$ number of spores of each species or genus of AMF.

The diversity expressed by the Shannon index indicated the agroforestry system as the most diverse system of AMF. Native forest presented significant lower diversity when compared to conventional corn and soybean. According to Siqueira et al. (1989), the diversity and sporulation of AMF is an indicator of the level of interference in natural ecosystems, because of low sporulation in native vegetation when compared to agroecosystems.

Low sporulation in native vegetation is related to the stability of the natural ecosystems, regarding the constant presence of hosts and absence of intense variations in the fertility of the soil. This contributes to the survival of species of these fungi with low natural sporulation capacity or that produce spores with low resistance to adverse conditions. In the conventional corn and soybean systems, which had the highest AMF spore densities, with areas under constant soil disturbance, such as plowing, which contributed to AMF stress and subsequent higher sporulation rates. In this survey, sample from soil under conventional cultivation systems contained large volumes of spores compared to the other systems. Stressful condition triggered by soil revitalization and fertilization processes probably caused the AMF to produce abundant amounts of infective propagules (Freitas et al., 2004).

The higher number of spores found in conventional soybean and corn planting may also have been influenced by changes in soil $\mathrm{pH}$ since these areas were previously corrected. According to Costa (2010), acidic soils that undergo liming interfere with the density of rhizosphere spores.

In addition to the 16 species recorded in the field (Table 3), it was recovered, through the trap culture technique, Rhizophagus sp. in the AFS and two new species: Rhizophagus intraradice and Scutellospora pernambucana in PCM. The technique was also efficient in other FMAs surveys conducted in the Brazil. Leal et al. (2009), for instance, evaluating arbuscular mycorrhizal fungi isolated in soil traps under different systems of use in the Amazon, recovered 24 species, having found the genera Acaulospora, Glomus, Entrophospora, Gigaspora, Archaespora, Scuttellospora and Paraglomus.

Differently of the values found in the study by Leal et al. (2009), a study carried out by Stürmer and Siqueira (2011) in different land use systems in the Amazon region, evaluating the richness and abundance of FMAs, verified the 
occurrence of 61 morphotypes. Despite the low number of FMAs diversity found in our survey, diversity may be underestimated, since not all components of the mycorrhizal community are in the spores form (reproductive structure that allows species to be morphologically identified) at the time of sampling, making it impossible his discrimination during the survey (Bartz et al., 2008).

Canonical analysis highlighted the correspondence between the AMF species and chemical attributes in the studied soil use and management systems (Figure 1). In the first axis, the influence of the SOM attributes, $\mathrm{Al}^{3+}$ and $\mathrm{H}+\mathrm{Al}$, was strong, which probably caused greatest AMF species richness in the agroforestry system (AFS). These were the factors that most contributed to the separation of AFS samples from the other systems.

According to Stürmer and Siqueira (2008), the majority of studies of the occurrence of AMF tends to consider fungal species diversity to be linked to physical and chemical soil properties, although most recognize the difficulties in establishing an exact relationship between different edaphic and environmental variables and the occurrence and diversity of AMF. In particular, levels of MOS and Al suggest the occurrence of spatial heterogeneity in AMF diversity, spore abundance and species richness, especially in natural ecosystems and anthropized habitats (Davison et al., 2015). However, chemical properties of the soil alone are not sufficient to explain the diversity of AMF present in AFS. It is likely that the diversity and productivity of these plant communities are closely linked to the greater diversity of AMFs (Van Der Heijden et al., 1998).

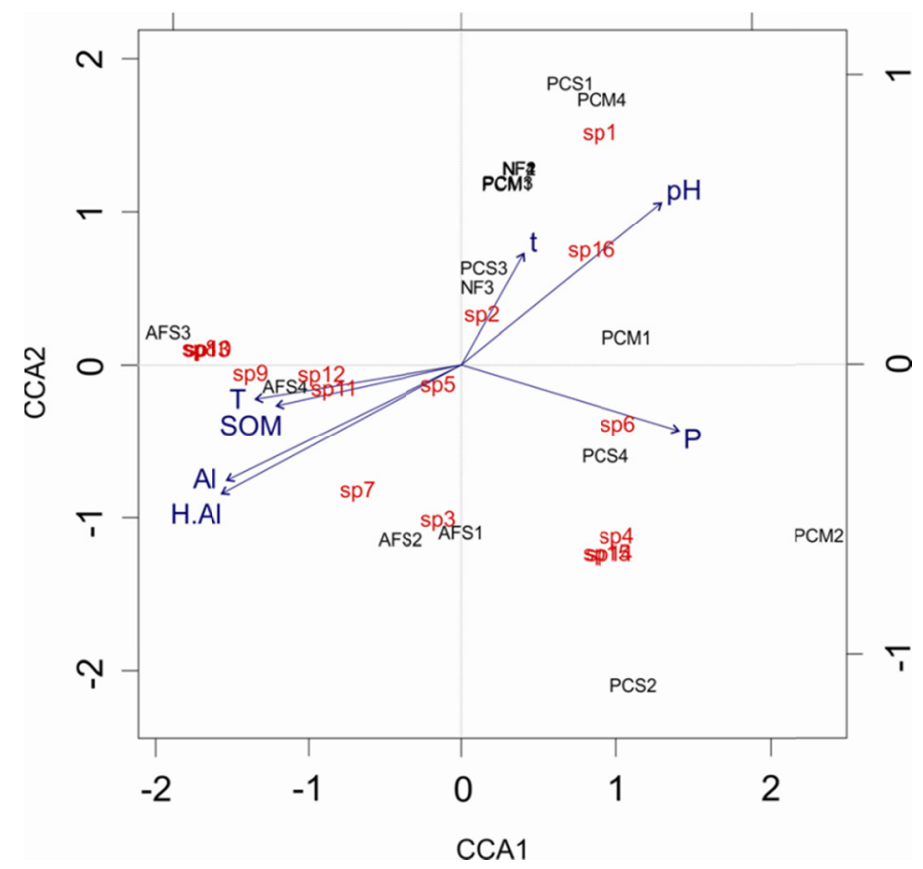

Figure 1. Ordination diagram of the canonical correspondence analysis (CCA) for 16 AMF species found in the different land use and management systems in Roraima state, northern Brazil. Species or genera of FMAs (sp1 to sp16 are shown in Table 3)

In the Dendogram constructed with Bray Curtis coefficient, AFS2, AFS3 and AFS4 areas are associated regarding AMF species composition, with NF3 and PCS2 present in the same group (Figure 2). Agroforestry generally increases the quantity of AMF spores when compared to the others systems of soil use (Loss et al., 2009; Udawatta et al., 2019). Management of the soil can also changes AMF composition (Fernandes, 2009) probably contributing to maintain a similar microbial community among agroforestry environments. In turn, PCM2 shows the most different pattern of species composition, probably due the exclusive occurrence of Dentiscutata heterogama in this sample. 


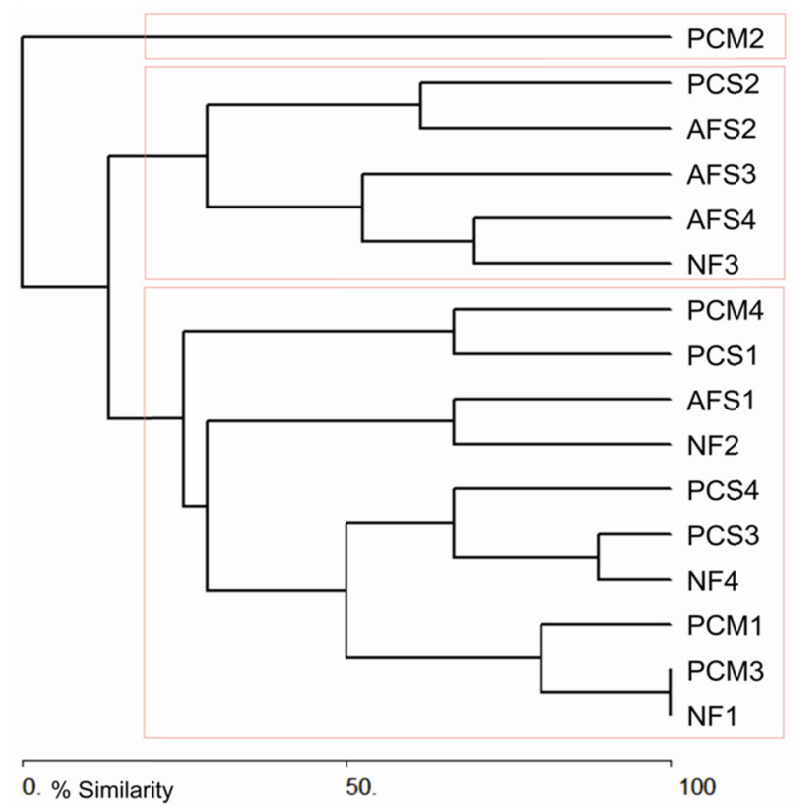

Figure 2. Dendogram of AMF similarity in different systems of land use and soil management

Note. Areas of native forest (NF), agroforestry system (AFS), conventional soybean (PCS) and conventional corn planting (PCM).

\section{Conclusions}

Roraima soils are acidic, extremely nutrient-poor, and costantly exposed to high-temperatures. Under such circumstances, arbuscular mycorrhizal fungi (AMF) are probably of key importance for the nutrition of regional tree species, improvement of soil structure and, consequently, greatly beneficial to land use and management systems like AFS. The richness of AMF species varied between systems and low diversity found in nature forest highlight the stability of the natural ecosystems. The genera Acaulospora and Glomus appeared to be unaffected by the environmental characteristics of the different agroecosystems.

AFS had a positive influence on the composition of the arbuscular mycorrhizal fungi community. AFS areas followed by conventional soybean planting were the systems with the most mycorrhizal fungi species, while the native forest and conventional corn systems were more restricted in the number of species of these fungi identified from their soils. Thus, AFS constitute sustainable alternative influencing AMF communities in these ecosystems.

\section{References}

Bartz, M. L. C., Carrenho, R., Gomes-da-Costa, S. M., Colozzi Filho, A., \& Tormena, C. A. (2008). Comparação entre as técnicas de amostragem direta em campo e cultura-armadilha para mensuração da diversidade de espécies de fungos micorrízicos arbusculares. Hoehnea, 35, 159-164. https://doi.org/10.1590/S2236-8906 2008000100010

Benedetti, U. G., Vale Júnior, J. F. do, Schaefer, C. E. G. R., Melo, V. F., \& Uchôa, S. C. P. (2011). Gênese, química e mineralogia de solos derivados de sedimentos pliopleistocênicos e de rochas vulcânicas em Roraima, norte amazônico. Revista Brasileira de Ciências do Solo, 35, 299-312. https://doi.org/10.1590/ S0100-06832011000200002

Carneiro, M. A. C., de Souza, E. D., dos Reis, E. F., Pereira, H. S., \& de Azevedo, W. R. (2009). Atributos físicos, químicos e biológicos de solo de Cerrado sob diferentes sistemas de uso e manejo. Revista Brasileira de Ciência do Solo, 33, 147-157. https://doi.org/10.1590/S0100-06832009000100016

Costa, R. S. C., Costa, N. L., Mendes, A. M., \& Rodrigues, V. G. S. (1999). Ocorrência de fungos MA em diferentes sistemas de uso da terra em Rondônia e Acre, Brasil (p. 11). Porto Velho: EMBRAPA-CPAF Rondônia. 
Costa, R. S. C. (2010). Micorrizas arbusculares em sistemas agroflorestais em duas comunidades rurais do Amazonas. Tese de Doutorado (Doutorado em Biotecnologia, Universidade Federal do Amazonas, Manaus, Brazil).

Fernandes, R. A. (2009). Impacto de usos de um Latossolo Vermelho de cerrado sobre a diversidade de fungos micorrízicos arbusculares (Dissertação (Mestrado em Agronomia), Universidade Federal de Goiás, Jataí).

Freitas, M. S. M., Martins, M. A., \& Vieira, I. J. C. (2004). Produção e qualidade de óleos essenciais de Mentha arvensis em resposta à inoculação de fungos micorrízicos arbusculares. Pesquisa Agropecuária Brasileira, 39(9), 887-894. https://doi.org/10.1590/S0100-204X2004000900008

Gerdemann, J. W., \& Nicolson, T. H. (1963). Spores of mycorrhizal endogone species extracted from soil by wet sieving and decanting. Transactions of the BritishMycological Society, 46(2), 235-244. https://doi.org/ 10.1016/S0007-1536(63)80079-0

Gianinazzi, S., Gollotte, A., Binet, M. N., Van Tuinen, D., Redecker, D., \& Wipf, D. (2010). Agroecology: The key role of arbuscular mycorrhizas in ecosystem services. Mycorrhiza, 20(8), 519-530. https://doi.org/ $10.1007 / \mathrm{s} 00572-010-0333-3$

Hoogland, D. C., \& Arnon, D. I. (1950). The water culture method of growing plants without soil. Berkeley, University of California.

INVAM. (2019). International Culture Collection of (Vesicular) Arbuscular Mycorrhizal Fungi. West Virginia University, USA.

Leal, P. L., Stürmer, S. L., \& Siqueira, J. O. (2009). Occurrence and Diversity of arbuscular mycorrhizal fungi in trap cultures from soils under different land use systems in the Amazon, Brazil. Brazilian Journal of Microbiology, 40, 111-121. https://doi.org/10.1590/S1517-83822009000100019

Loss, A., Angelini, G. A. R., Pereira, A. C. C., Lã, O. R., Magalhães, M. O. L., Silva, E. M. R., \& Saggin Junior, O. J. (2009). Atributos químicos do solo e ocorrência de fungos micorrízicos sob áreas de pastagem e sistema agroflorestal, Brasil. Acta Agron (Palmira), 58(2), 91-95.

Mourão, M., Xaud, H. A. M., Arco-Verde, M. F., Tonini, H., \& Moura Neto, M. A. (2003). Precipitação pluviométrica em áreas de transição savana-mata de Roraima: Campos experimentais Serra da Prata e Confiança. Comunicado Técnico. Embrapa Roraima.

Nicolodi, M., Anghinoni, I., \& Salet, R. L. (2002). Alternativa à coleta de uma secção transversal. com pá de corte, na largura da entrelinha, na amostragem do solo em lavouras com adubação em linha no sistema plantio direto. Revista Plantio Direto, 69(1), 22-28.

Oehl, F., Sieverding, E., Ineichen, K., Mäder, P., Boller, T., \& Wiemken, A. (2003). Impact of land use intensity on the species diversity of arbuscular mycorrhizal fungi in agroecosystems of Central Europe. Applied and Environmental Microbiology, 69(5), 2816-2824. https://doi.org/10.1128/AEM.69.5.2816-2824.2003

Oliveira, L. A., Guitton, T. B., \& Moreira, F. W. (1999). Relações entre as colonizações por Fungos Micorrízicos Arbusculares e teores de nutrientes foliares em oito espécies florestais da Amazônia. Acta Amaz, 29(2), 183-193. https://doi.org/10.1590/1809-43921999292193

Perlatti, F. (2010). Diversidade de fungos micorrízicos arbusculares no solo de agrossistemas e mata nativa em ambiente semiárido no Ceará (Dissertação de Mestrado, Universidade Federal do Ceará, Fortaleza).

R Core Team. (2018). R: A Language and Environment for Statistical Computing. R Foundation for Statistical Computing, Vienna. Retrieved from https://www.R-project.org

Salton, J. C., Mielniczuk, J., Bayer, C., Boeni, M., Conceição, P. C., Fabrício, A. C., ... Broch, D. L. (2008). Soil aggregation and aggregate stability under crop-pasture systems in Mato Grosso do Sul State, Brazil. Revista Brasileira de Ciência do Solo, 32(1), 11-21. https://doi.org/10.1590/S0100-06832008000100002

Shuklha, M. K., Lal, R., \& Ebinger, M. (2006). Determining soil quality indicators by factor analysis. Soil and Tillage Research, 87(2), 194-204. https://doi.org/10.1016/j.still.2005.03.011

Siqueira, J. O., Colozzi-Filho, A., \& Oliveira, E. (1989). Ocorrência de micorrizas vesicular-arbusculares em agro e ecossistemas do Estado de Minas Gerais. Pesquisa Agropecuária Brasileira, 24(12), 1499-1506.

Stürmer, S. L., \& Siqueira, J. O. (2011). Species richness and spore abundance of arbuscular mycorrhizal fungi across distinct. land uses in western Brazilian Amazon. Mycorrhiza, 21(4), 255-26. https://doi.org/10.1007/ s00572-010-0330-6 
Stürmer, S. L., \& Siqueira, J. O. (2008). Diversidade de fungos micorrízicos arbusculares em ecossistemas brasileiros. In F. M. S. Moreira, J. O. Siqueira, \& L. Brussaard (Eds.), Biodiversidade do solo em ecossistemas brasileiros (Cap. 16, pp. 537-583). Lavras: UFLA.

Stürmer, S. L., Kemmelmeier, K., Moreira, B. C., Kasuya, M. C. M., Pereira, G. M. D., \& da Silva, K. (2018). Arbuscular mycorrhizal fungi (Glomeromycota) communities in savannas of Roraima. Brazil. Mycol Progress, 17, 1149. https://doi.org/10.1007/s11557-018-1430-5

Trindade, A. V., Grazziotti, P. H., \& Tótola, M. R. (2000). Utilização de características microbiológicas na avaliação da degradação ou recuperação de área sob mineração de ferro. Revista Brasileira de Ciência do Solo, 24(1), 683-688. https://doi.org/10.1590/S0100-06832000000300022

Udawatta, R. P., Rankoth, L. M., \& Jose, S. (2019). Agroforestry and Biodiversity. Sustainability, 11, 1-22. https://doi.org/10.3390/su11102879

Van Der Heijden, M. G. A., Bardgett, R. D., \& Van Straalen, N. M. (2008). The unseen majority: Soil microbes as drivers of plant diversity and productivity in terrestrial ecosystems. Ecology Letters, 1(3), 296-310. https://doi.org/10.1111/j.1461-0248.2007.01139.x

Vendrame, P. R. S., Eberhardt, D. N., Brito, O. R., Marchão, R. L., Quantin, C., \& Becquer, T. (2011). Formas de Ferro e Alumínio e suas relações com textura, mineralogia e cabono orgânico em Latossolos do Cerrado. Semina. Ciências Agrárias, 32. https://doi.org/10.5433/1679-0359.2011v32Suplp1657

\section{Copyrights}

Copyright for this article is retained by the author(s), with first publication rights granted to the journal.

This is an open-access article distributed under the terms and conditions of the Creative Commons Attribution license (http://creativecommons.org/licenses/by/4.0/). 